\title{
Plagiarism: to what extent it is understood?
}

\author{
Wan Zah Wan Ali*, Habsah Ismail \& Tan Tien Cheat \\ Department of Foundation of Education, Faculty of Educational Studies, Universiti Putra Malaysia
}

\begin{abstract}
Plagiarism has been identified as a problem since the $1600 \mathrm{~s}$. Nevertheless, this problem is becoming more alarming with the use of internet which provides the avenue for easy access for a student to plagiarise. This unethical act must be prevented to ensure that students' behaviour and integrity are in line with moral virtues and values. Based on literature, one of the ways to overcome this problem is to examine students' understanding of the concept of plagiarism. Hence, a study had been carried out amongst the university students aimed at identifying the extent of students' understanding of the concept of plagiarism through the use of computer and information technology. This study used the survey method involving 327 students and data was collected through administration of a questionaire. This paper will thus discuss the findings of the study together with its implications in the effort to overcome the issue of plagiarism amongst students.
\end{abstract}

(C) 2011 Published by Elsevier Ltd. Selection and/or peer reviewed under responsibility of the UKM Teaching and Learning Congress 2011 Open access under CC BY-NC-ND license.

Keyword: Higher education; ICT; plagiarism

\section{Introduction}

In western countries especially the United Kingdom, United State and Australia, plagiarism is not a new problem (Wang, 2008). In his report, 'Combating Plagiarism', Hansen (2003), revealed that the problem of plagiarism in the west had started as early as the 1600s. During this time, students plagiarised from printed materials such as books, journals, magazines and other sources that were available in the libraries (McKenzie, 1998).

Since the year 1990, technology and communication technology (ICT) had become very popular amongst the students and thus, their methods of plagiarism had also changed (Hansen, 2003). The facilities provided by ICT such as the internet had made it easy for students to retrieve information by merely clicking the mouse (Sisti, 2007; Wang, 2008). The information obtained from the internet made it possible for students to save and to 'cut and paste' with ease compared to information obtained from text books, journals or magazines (Dunn, Morgan, O'Reilly \& Parry, 2003; Iroins, 2004; Scanlon, 2003; Schiller, 2005). In other words, the use of ICT can hasten the act of plagiarising compared to the period before this (Boisvert \& Irwin, 2006; Kasprzak \& nixon, 2004; McCabe, 20010.

* Corresponding author. Tel.: +603-8946-6044; fax: +603-8946-8246

E-mail address: wanzah@educ.upm.my 
This point is also supported by Miall (2005), Jones, Reid and Bartlett (2005) when they assert that ICT is a new device that enables students to plagiarise much faster.

The question now, is ICT the only factor that contributes to this problem? Past studies (as in Park 92003), Sheard, Markham, and Dick (2003), Marshall and Gary (2005) also Smith, Noorlaila Ghazali, and Siti Fatimah Noor Minhad (2007) have shown that there are many factors that contribute to plagiarism becoming increasingly problematic. Among the problems are students' understanding of plagiarism, their self-realization, ethics and personal attitude, internet access, pressure and learning environment.

Amongst the problems cited above, Introna, Hayes, Blair, and Wood (2003), Ma, Lu, Turner, and Wan (2007) and also Yeo (2007), agree that the understanding of the concept of plagiarism through the use of ICT is the main contributor to it being a problem. As cited in Introna et al. study (2003), university students in Greece who plagiarised through the use of internet believed that the information in the internet was in the 'public domain'. Thus whatever information or statements in the internet, is for public use. Therefore, they believed that was not wrong to download, edit and print an article or book from a website and then claimed that the article or information as their own original writing. This belief is further strengthened when their peers who were doing this sort of acts were not being reprimanded from the authority concerned (Sisti, 2007).

This situation shows that different contexts will give rise to different meanings of plagiarism (Shelley in Ercfegovac \& Richardson, 2004). As such, there is a need to carry out a study in the local context pertaining to plagiarism.

Taking this view into consideration, a study was conducted amongst students of Universiti Putra Malaysia to identify the extent of their understanding of the concept of plagiarism in the ICT context. This study also examines which aspect of the understanding is the most accepted in terms of plagiarism and vice versa.

\section{Methodology}

This is a descriptive study using the survey method. This method is suitable in terms of the aim of the study which seeks to obtain a general perspective on the status of students' understanding of the plagiarism concept.

Population of the study consists of 1565 students from the Bachelor of Education programme in Universiti Putra Malaysia. Based on purposive sampling, 377 students from the final year of the programme were selected as samples of study. These final year students were chosen due to their maturity level based on their learning experience in the university and were enmbarking on their profession. As such, thier views were assumed to represent the views of all the other students of the programme chosen.

The instrument used in this study is a questionairre comprising of two sections namely Section A which consists of the student's profile such as gender, ethnic, and cumulative grade point average (CGPA). Section B consists of 13 items on the concept of plagiarism through the use of ICT which were adapted from Sheard, Markham, and Dick (2003) and also Marshall and Gary (2005). Of the 13 items, three items do not describe the act of plagiarising and the rest of the items are otherwise. Students only need to circle the "No' or "Yes' based on their perception in the space proved for every statement. Table 1 shows the items based on the category of answers given.

$\underline{\text { Table 1. Answer to item measured }}$

Items showing non-plagiarism through use of ICT
(No)
Items showing plagiarism using ICT

(Yes)

To me, plagiarism through the use of ICT means

2. copying statements from websites with proper references or achnowledging the original author/writer

4. copying statemetns from electronic journals with proper references or acknowledging original author/writer
1. copying statemetns from websites without citing the proper references and acknowledging the original author/writer.

3. copying statemetns from electronic journals without citing the references or achnowledging the original author/writer. 
6. translating and making own statemetns in another language (for example Malay to English Language) from the internet and acknowledging the original author/writer
5. copying sources of reference without

(" ") but cites proper references or acknowledging the original author/writer.

7. combining various statemetns taken from websites in an assignment without citing proper references or acknowledging original author/writer.

8. change original statement taken from websites and presenting it as own assignment.

9. buying an assignment from senior students and submitting it as own assignment.

10. using the work of other authors/writers from the internet and claiming it as own assignment without acknowledging the original author/writer.

11. use research findings (for example statistics, diagrams, tables etc.) from electronic journals inassignment without citing proper references or acknowledging original aquthor/writer.

12. copying friends' assignment using computer without their knowledge

13. copying friends' assignment using internet and submitting it as own assignment without their knowledge

\section{Findings of Study}

\subsection{Students' profile}

Table 2 shows the number and percentage of university students according to gender, ethnic and CGPA. This study involves $91(28 \%)$ male students and $236(72 \%)$ female students. The number and percentage of respondents comprised of $282(86 \%)$ Malay $25(8 \%)$ Chinese, $12(4 \%)$ Indian and $8(2 \%)$ other respondents consisting of the indigenuous ethnic group of Sabah and Sarawak (Bidayuh, Bisaya, Rungus, Kadazan, Dusun and Kayan). In term of CGPA, majority of students $(86.5 \%)$ are between $3.00-4.00$, only $13.5 \%$ are between $2.00-2.99$ and none of them get less than 2.00 .

Table 2. Respondents' profile

\begin{tabular}{llcc}
\hline Demography & & Frequency $(f)$ & Percentage (\%) \\
\hline Gender & Male & 91 & 28 \\
& Female & 236 & 72 \\
Ethnic & Malay & 282 & 86 \\
& Chinese & 25 & 8 \\
& Indian & 12 & 4 \\
& Others & 8 & 2 \\
CGPA & & & \\
& $3.00-4.00$ & 283 & 86.5 \\
& $2.00-2.99$ & 44 & 13.5 \\
\hline
\end{tabular}

\subsection{The status of university students' understanding of the concept of plagiarism through the use of ICT}

Based on data analysis, respondents of study obtain a score of 0 till 13, or maximum score. The highest score obtained by majority of respondents is 11 . However, the mean score is 8 , and the median is 9 . Table 3 shows the distribution of score on students' understanding of the plagiarism concept. 
Table 3. Score for understanding of plagiarism concept through the use of ICT

\begin{tabular}{ccccc}
\hline Score & $\begin{array}{c}\text { Frequency } \\
(f)\end{array}$ & $\begin{array}{c}\text { Percentage } \\
(\%)\end{array}$ & $\begin{array}{c}\text { Cumulative } \\
\text { Frequency }\end{array}$ & Total score \\
\hline 0 & 4 & 1.2 & 4 & 0 \\
1 & 12 & 3.7 & 16 & 12 \\
2 & 17 & 5.2 & 33 & 34 \\
3 & 21 & 6.4 & 54 & 63 \\
\hline 4 & 13 & 4.0 & 67 & 52 \\
5 & 17 & 5.2 & 84 & 85 \\
\hline 6 & 19 & 5.8 & 103 & 114 \\
\hline 7 & 24 & 7.3 & 127 & 168 \\
\hline 8 & 20 & 6.1 & 147 & 160 \\
\hline 9 & 38 & 11.6 & 185 & 342 \\
10 & 48 & 14.7 & 233 & 480 \\
11 & 51 & 15.6 & 284 & 561 \\
\hline 12 & 38 & 11.6 & 322 & 456 \\
13 & 5 & 1.5 & 327 & 65 \\
Total & 327 & 100 & & 2592 \\
\hline
\end{tabular}

Mean score of answers $=8$, Median score of answers $=9$

Total number of students with score $\geq 8=200(61.2 \%)$

Total number of students with score $\geq 9=180(55.0 \%)$

Based on Table 3, the number of respondents who suceeded in obtaining mean scores and above mean $\geq 8$ is 200 or $61.2 \%$ of the total number of respondents. The number of respondents who suceeded in obtaining median scores and above is 188 or $55.0 \%$. This means that more than half of the total number of respondents succeeded in giving the right answers to 8-13 items which examine their understanding of the plagiarism concept. The visual form of this score distribution is shown by the Chart 1 below.

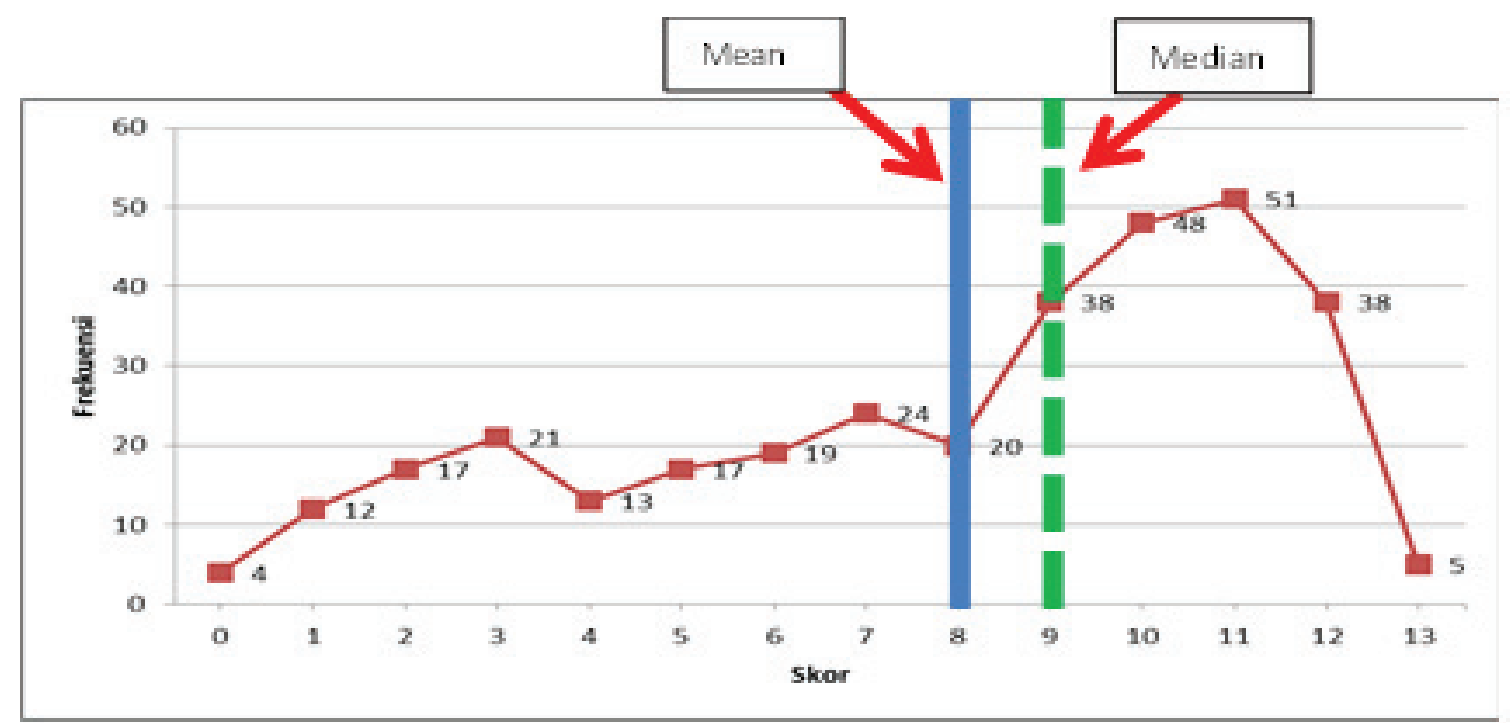

Figure 1. Score for understanding of plagiarism concept through the use of ICT

If the mean score is used as the basis to determine the level of understanding, findings show that respondents on the whole only understand $61.5 \%$ of the plagiarism concept. If median is used to determine their level of understanding, it was found that only $69.2 \%$ of the plagiarism concept through the use of ICT was understood. Assuming if the number of respondents who obtained a score of 8 and above is considered, then only $200(61.2 \%)$ of 
respondents understood $61.5 \%$ to $100 \%$ of the concept of plagiarism. The level of understanding of the plagiarism concept was found to be between $69.2 \%-100 \%$ if the median score is used which involves $180(55 \%)$ respondents. Table 4 shows the students' level of understanding based on their mean and median scores.

Table 4. University students' understanding of plagiarism concept through the use of ICT based on mean and median

\begin{tabular}{lccc}
\hline Score & No. of Students & Percentage of Students & Percentage of understanding \\
\hline Mean $\geq 8$ & 200 & 61.2 & $61.5-100$ \\
Median $\geq 9$ & 180 & 55 & $69.2-100$ \\
\hline
\end{tabular}

A closer examination of the level of understanding among respondents of the plagiarism concept can be seen in Table 5 which shows the score distribution and understanding level.

Table 5. Score distribution and understanding level

\begin{tabular}{cccc}
\hline Score & Frequency $(f)$ & Percentage(\%) & $\begin{array}{c}\text { Level of } \\
\text { Understanding (\%) }\end{array}$ \\
\hline 0 & 4 & 1.2 & 0 \\
1 & 12 & 3.7 & 7.6 \\
2 & 17 & 5.2 & 15.3 \\
3 & 21 & 6.4 & 23 \\
4 & 13 & 4.0 & 30.7 \\
5 & 17 & 5.2 & 38.4 \\
6 & 19 & 5.8 & 46.1 \\
7 & 24 & 7.3 & 53.8 \\
\hline 8 & 20 & 6.1 & 61.5 \\
9 & 38 & 11.6 & 69.2 \\
10 & 48 & 14.7 & 76.9 \\
11 & 51 & 15.6 & 84.6 \\
12 & 38 & 11.6 & 92.3 \\
13 & 5 & 1.5 & 100 \\
Total & 327 & 100 & \\
\hline
\end{tabular}

Based on Table 5, the highest score obtained by majority of respondents, totalling $51(15.6 \%)$, is 11 and this shows that they understood $84.6 \%$ of the plagiarism concept. The second highest score is 10 which was obtained by $48(14.7 \%)$ respondents, and this shows that they understood $76.9 \%$ of the plagiarism concept. There is in addition $1.5 \%$ of respondents who understood $100 \%$ of the plagiarism concept and $1.2 \%$ who did not understand it at all.

A detailed analysis of the university students' answers of the 13 items on their understanding of the plagiarism concept (Table 6), found that 7 items that were correctly answered belonged to more than $60 \%$ category. For example, for item 1 (copying a statement form the website without putting the proper reference or without acknowledging the original writer), was correctly answered by 755 (246) respondents. Besides this, there were 233 or $71 \%$ of respondents who could identify item 10 correctly. This means that most of respondents could identify that using the works of other authors from the internet and claiming it to be one's own work without the author's knowledge, is a plagiarising act.

Item 11 (using the findings of research (for example, statistic, diagrams, tables etc.) from electronic journals in one's assignment without proper reference or without acknowledging the original author), item 3 (copying statement from electronic journal without proper reference or without proper acknowledgment to original author/writer) and item 7(combining various statements taken from websites and using them in assignments without proper reference or without acknowledging original author) also obtained higher percentage, $69 \%, 68 \%$ and $64 \%$ respectively. This shows that respondents' understanding of the plagiarism concept based on the aspects mentioned above is rather satisfactory.

Nevertheless, findings also show that the high percentage of students' did not give accurate answers. For example, item 6 (translating and constructing own sentence/statement into another language (for instance the Malay Language 
into the English Language) from the internet and acknowledging original writer). Two hundred and seventeen (66\%) respondents have chosen this statement as "Yes" even though this statement is not a plagiarising act.

Table 6. University students' understanding of plagiarism concept through the Use of ICT

\begin{tabular}{|c|c|c|c|}
\hline \multirow{3}{*}{$\begin{array}{l}\text { Item } \\
\text { To me, plagiarism through the use of ICT means }\end{array}$} & \multirow{3}{*}{ 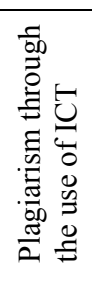 } & \multicolumn{2}{|c|}{$\begin{array}{l}\text { Respondents' } \\
\text { Feedback } \\
(\mathrm{n}=327)\end{array}$} \\
\hline & & $\begin{array}{l}\text { No } \\
f \\
(\%)\end{array}$ & $\begin{array}{l}\text { Yes } \\
f \\
(\%)\end{array}$ \\
\hline & & & \\
\hline $\begin{array}{l}\text { copying statements from websites without stating the proper reference or } \\
\text { acknowledging the original author. }\end{array}$ & Yes & $\begin{array}{c}81 \\
(25)\end{array}$ & $\begin{array}{l}246 \\
(75)\end{array}$ \\
\hline $\begin{array}{l}\text { copying statements from websites with proper references or } \\
\text { acknowledging the original author. }\end{array}$ & No & $\begin{array}{l}194 \\
(59)\end{array}$ & $\begin{array}{l}133 \\
(41)\end{array}$ \\
\hline $\begin{array}{l}\text { copying statements from from electronic journals without proper } \\
\text { references or without acknowledging the original author. }\end{array}$ & Yes & $\begin{array}{l}104 \\
(32)\end{array}$ & $\begin{array}{l}223 \\
(68)\end{array}$ \\
\hline $\begin{array}{l}\text { copying statements from electronic journals by citing proper references or } \\
\text { acknowledging original author. }\end{array}$ & No & $\begin{array}{l}191 \\
(58)\end{array}$ & $\begin{array}{l}136 \\
(42)\end{array}$ \\
\hline $\begin{array}{l}\text { copying source of statements without inverted comas (" ") but citing } \\
\text { proper references or acknowledging original author. }\end{array}$ & Yes & $\begin{array}{l}139 \\
(42)\end{array}$ & $\begin{array}{l}188 \\
(58)\end{array}$ \\
\hline $\begin{array}{l}\text { translating and constructing own sentences into another language (for } \\
\text { example, Malay language to English Language) from the internet and } \\
\text { acknowledging original author. }\end{array}$ & No & $\begin{array}{l}110 \\
(34)\end{array}$ & $\begin{array}{l}217 \\
(66)\end{array}$ \\
\hline $\begin{array}{l}\text { combining various statements taken from websites in an assignment } \\
\text { without proper reference or acknowledgement to the original author. }\end{array}$ & Yes & $\begin{array}{l}118 \\
(36)\end{array}$ & $\begin{array}{l}209 \\
(64)\end{array}$ \\
\hline $\begin{array}{l}\text { changing statements taken from websites and claiming them as your own } \\
\text { writing. }\end{array}$ & Yes & $\begin{array}{l}130 \\
(40)\end{array}$ & $\begin{array}{l}197 \\
(60)\end{array}$ \\
\hline $\begin{array}{l}\text { buying assignments from senior students through internet and sending } \\
\text { them as your own work/writing. }\end{array}$ & Yes & $\begin{array}{l}130 \\
(40)\end{array}$ & $\begin{array}{l}197 \\
(60)\end{array}$ \\
\hline $\begin{array}{l}\text { using the work of other writers from the internet as your own without prior } \\
\text { knowledge of the authors. }\end{array}$ & Yes & $\begin{array}{l}94 \\
(29)\end{array}$ & $\begin{array}{l}233 \\
(71)\end{array}$ \\
\hline $\begin{array}{l}\text { using research findings ( example statistics, diagrams, tables etc) from } \\
\text { electronic journals in your assignments without citing proper references or } \\
\text { acknowledging the original author. }\end{array}$ & Yes & $\begin{array}{l}101 \\
(31)\end{array}$ & $\begin{array}{l}226 \\
(69)\end{array}$ \\
\hline copying a friend's assignment using computer without his/her knowledge. & Yes & $\begin{array}{l}143 \\
(44)\end{array}$ & $\begin{array}{l}184 \\
(56)\end{array}$ \\
\hline $\begin{array}{l}\text { copying a friend's assignment using the internet and claiming it as your } \\
\text { own without his/her knowledge. }\end{array}$ & Yes & $\begin{array}{l}133 \\
(41)\end{array}$ & $\begin{array}{l}194 \\
(59)\end{array}$ \\
\hline
\end{tabular}

Besides, there are a few items that are not perceived as plagiarising acts as shown in the comparatively high percentage of agreement amongst some of the respondents;

1. Copying a friend's assignment using computer without his/her knowledge (44\%).

2. Copying a friend's assignment using the internet and claiming it as your own without his/her knoweldge $(41 \%)$.

3. Buying assignments from senior students through internet and sending them as your own work/writing. $(40 \%)$.

4. Changing statements taken from websites and claiming them as your own writing (40\%). 


\section{Discussion}

This study aims to identify the understanding of the plagiarism concept through the use of information technology and computer from the perspective of students from the Bachelor of Education programme at Universiti Putra Malaysia. The study was conducted based on the claim that the easy access to internet and computers had contributed greatly to plagiarism. However, this study assumes that the understanding of plagiarism is the main factor of the plagiarising act and that many students succumbed to it without their realising it. This is due to the various meanings of plagiarism based on certain contexts in which this study has revealed some interesting findings.

Based on data analysis, it can be generally concluded that students' understanding of the concept of plagiarism in this study, is still not satisfactory. In general, only $61.5 \%$ of the concept of plagiarism was understood by the respondents. Even though it cannot be denied that the highest score is the maximum score, the number is still small $(1.5 \%)$. This proves that the perception of plagiarism as being generally understood is wrong, especially when there are still respondents who do not understand the concept. This phenomenom must be studied in depth so that the concept of plagiarism can be fully understood.

This study also examines in detail the respondents' understanding of the concept of plagiarism. Majority of the respondents agree that copying, and using the works of others without acknowledging the original authors/writers are acts of plagiarism. However, question arises when there are about $40 \%$ of the respondents who perceive that copying their friends' assignment, buying assignments from seniors and changing statemetns from the sources obtained without acknowledging the original authors/writers are not considered as plagiarising acts.

Findings of this study hence, agree with studies by Introna, Hayes, Blair and Wood (2003), Ma, Lu, Turner and Wan (2007) as well as Yeo (2007) who state that students' understanding of the concept of plagiarism through the use of ICT is still limited. This is probably due to the concept itself having several meanings based on various contexts as claimed by Shelly (cited in Ercegovac \& Richardson, 2004).

Based on the fact above, it is important that the right concept of plagiarism to be made widely known in a more aggressive manner amongst the students through various activities such as seminars, campaigns and so forth. This concept can also be instilled in lectures or practical sessions so as to enable students to truly understand what is meant by plagiarism. With this right understanding, they can be prevented from plagiarising, an act commiteed without their awareness.

A point to note is, a misunderstood concept of plagiarism may lead to difficulty in eradicating plagiarising acts. To punish individuals who are not aware of indulging in plagiarism is not justified. Thus, instilling the understanding of plagiarism is a better task that must be implemented in a more serious manner. Students' level of understanding of plagiarism must be monitored from time to time through either a quantitative or qualitative survey or both.

\section{Conclusion}

Plagiarism is an unethical act and must be eradicated from the students' mindset. The consequence of it is not only on the students as it can also tarnish the good image of an institution. Studies have shown that plagiarism must not be taken lightly in view of the fact that understanding of the concept of plagiarism using the ICT is still unsatisfactory. An ongoing effort must be undertaken to instill the realization and understanding amongst the students on plagiarism to avoid their involvement in it in the future.

\section{References}

Belcheir, M. J. (2005). Academic dishonesty at Boise State University (Research Report). Boise: Boise State University, Office of Institutional Assessment.

Boisvert, R. F., \& Irwin, M. J. (2006). Plagiarism on the rise. Communications of the ACM, 49(6), 23-24. Retrieved from http://delivery.acm.org/10.1145/1140000/1132487/p23-

boisvert.pdf?keyl=1132487\&key2=2589856421\&coll=ACM\&dl=ACM\&CFID=42618460\&CFTOKEN=34349395. doi:http://doi.acm.org/10.1145/1132469.1132487

Devlin, M., \& Gray, K. (2007). In their own words: A qualitative study of the reasons Australian university students plagiarize. Higher Education Research \& Development, 26(2), 181-198. Retrieved from http://www.informaworld.com/10.1080/07294360701310805 
Dunn, L., Morgan, C., O'Reilly, M., \& Parry, S. (2003). Academic fraud and plagiarism. In L. Dunn, C. Morgan, M. O'Reilly \& S. Parry (Eds.), The Student Assessment Handbook (pp. 59-66). London: Routledge.

Ercegovac, Z., \& Richardson, J. J. V. (2004). Academic dishonesty, plagiarism included, in the digital age: A literature review. College \& Research Libraries, 301-318. Retrieved from http://www.ftrf.org/ala/mgrps/divs/acrl/publications/crljournal/2004/jul/ercegovac.pdf

Hansen, B. (2003). Combating plagiarism. CQ Researcher, 13(32), 773-796. Retrieved from http://www.cqpress.com/docs/Combating\%20Plagiarism.pdf

Introna, L., Hayes, N., Blair, L., \& Wood, E. (2003). Cultural attitudes towards plagiarism. Lancaster: University of Lancaster.

Irons, A. (2004). Reducing plagiarism in computing. In A. Irons \& S. Alexander (Eds.), Effective Learning and Teaching in Computing (pp. 100110). London: Routledge.

Jones, K. O., Reid, J. M. V., \& Bartlett, R. (2005). Student plagiarism and cheating in an IT age. Paper presented at the International Conference on Computer Systems and Technologies, CompSysTech' 2005.

Kasprzak, J. E., \& Nixon, M. A. (2004). Cheating in cyberspace: Maintaining quality in online education. Association for the Advancement of Computing In Education, 12(1), 85-99. Retrieved from http://www.editlib.org/?fuseaction=Reader.ViewFullText\&paper_id=1733

Ma, H. J., Lu, E., Turner, S., \& Wan, G. (2007). An empirical investigation of digital cheating and plagiarism among middle school students. American Secondary Education, $\quad 35(2), \quad 69-82 . \quad$ Retrieved http://search.ebscohost.com/login.aspx?direct=true\&db=a3h\&AN=24895456\&site=ehost-live

Marshall, S., \& Garry, M. (2005). How well do students really understand plagiarism. Paper presented at the Proceedings of the 22nd annual conference of the Australasian Society for Computers in Learning in Tertiary Education (ASCILITE). Retrieved 17 February 2009 , from http://www.ascilite.org.au/conferences/brisbane05/blogs/proceedings/52_Marshall.pdf

McCabe, D. (2001). Cheating: Why students do it and how we can help them stop. American Educator, 25(4), 38-43. Retrieved from http://www.aft.org/pubs-reports/american_educator/winter2001/Cheating.html

McKenzie, J. (1998). The new plagiarism: Seven antidotes to prevent highway robbery in an electronic age. The Educational Technology Journal, 7(8). Retrieved from http://www.fno.org/may98/cov98may.html

Miall, C. (2005). Plagiarism and new media technologies: Combating 'cut' n 'paste' culture. Paper presented at the OLT-2005 Conference, Queensland University of Technology, Brisbane.

Park, C. (2003). In other (people's) words: Plagiarism by university students-literature and lessons. Assessment \& Evaluation in Higher Education, 28(5), 471-488. Retrieved from http://www.informaworld.com/10.1080/02602930301677

Scanlon, P. M. (2003). Student online plagiarism: How do we respond? College Teaching, 51(4), 161-166. Retrieved from http://www.accessmylibrary.com/coms2/summary_0286-20239508_ITM

Schiller, M. R. (2005). E-cheating: Electronic plagiarism. Journal of the American Dietetic Association, 105(7), 1058-1062. Retrieved from http://www.sciencedirect.com/science/article/B758G-4GGGD7K-F/2/f850d647186f99e84a370f09cca6e8a1

Sheard, J., Markham, S., \& Dick, M. (2003). Investigating differences in cheating behaviours of IT undergraduate and graduate students: The maturity and motivation factors. Higher Education Research \& Development, 22(1), 91-108. Retrieved from http://www.it.uu.se/edu/course/homepage/datadidaktik/ht07/teaching/Investigating\%20Cheating\%20HERD\%202003.pdf

Sisti, D. A. (2007). How do high school students justify internet plagiarism? Ethics \& Behavior, 17(3), 215-231. Retrieved from http://www.informaworld.com/10.1080/10508420701519163

Smith, M., Noorlaila Ghazali, \& Siti Fatimah Noor Minhad (2007). Attitudes towards plagiarism among undergraduate accounting students: Malaysian evidence. Asian Review of Accounting, 15(2), 122-146. Retrieved from http://www.emeraldinsight.com/Insight/viewPDF.jsp?contentType=Article\&Filename=html/Output/Published/EmeraldFullTextArticle/Pdf/3 410150202.pdf

Straw, D. (2002). The plagiarism of generation 'why not?'. Community College Week, 14(24), 4-7.

Szabo, A., \& Underwood, J. (2004). Cybercheats: Is information and communication technology fuelling academic dishonesty? Active Learning in Higher Education, 5(2), 180-199. Retrieved from http://alh.sagepub.com/cgi/content/abstract/5/2/180. doi:10.1177/1469787404043815

Wang, Y. M. (2008). University student online plagiarism. International Journal on E-Learning, 7(4), 743-757. Retrieved from http://search.ebscohost.com/login.aspx?direct=true\&db=eric\&AN=EJ810080\&site=ehost-live http://www.editlib.org/index.cfm?fuseaction=Reader.ViewAbstract\&paper_id=24455

Yeo, S. (2007). First-year university science and engineering students' understanding of plagiarism. Higher Education Research \& Development, 26(2), 199-216. Retrieved from http://www.informaworld.com/10.1080/07294360701310813 